\title{
Gwałt jako instytucja w czasie wojen i ludobójstw
}

\author{
Rape as an Institution During War and Genocide
}

Aвstract: This article discusses five non-formal institutions of rape from the perspectives of historical sociology and genocide studies, distinguishing types of rape on the basis of a comparative historical analysis of ten cases: (1) rape as reward for soldiers and other combatants; (2) rape as a method of initiating soldiers, integrating the military group, and legitimating masculinity; (3) rape as an offensive institution, fulfilling two functions: (3.1) symbolic attack on an enemy group; (3.2) increasing damage/cost to the enemy by making their lives harder in terms of trauma to women, the raising of unwanted children, and so on; (4) rape as a method of ethnic cleansing; (5) rape as a form of genocide. The five types of rape are regarded as institutions: expressions of culturally fixed values and norms which determine accepted goals and the methods of attaining those goals and are embedded in the subcultures of particular organizations (the army, the police, party militia groups, etc.). Not every rape is related to these institutions. In this sense, rapes can be regarded by members of a particular organization as justified or unjustified. Moreover, perpetrators may feel institutionally compelled to engage in the raping of victims.

KEY wORDS: genocide studies, historical sociology, historical comparative research, rape, institution of rape

Gwałty są najprawdopodobniej tak stare, jak gatunek ludzi. Psychologowie ewolucyjni wyjaśniają ich występowanie, odwołując się do korzyści, jakie przynosiły mężczyznom ${ }^{1}$. W artykule interesuje mnie jednak gwałt jako instytucja funkcjonująca w czasie wojen i ludobójstw. Instytucję rozumiem tu szeroko - to względnie trwałe i niezależne elementy kultury, zespół wartości (określających cele działania) i norm (określających sposoby ich osiągania). Jest to więc intersubiektywny twór społeczny, wymagający akceptacji przez przynajmniej część

\footnotetext{
${ }^{1}$ Por. D. Buss: Psychologia ewolucyjna. Przeł. M. Orski. Gdańsk 2001, s. 331-332, 365.
} 
członków społeczeństwa. Poprzestanę na tej ogólnej definicji instytucji, odwołując się w miarę potrzeby do wybranych teorii socjologicznych. Instytucjami w naukach społecznych zajmuje się wiele nurtów, w tym nowy instytucjonalizm ${ }^{2}$.

Gwałty w większości nie są instytucjami formalnymi, choć mogą być akceptowane w takich instytucjach jako część subkultury. W artykule zamierzam przedstawić typologię instytucji gwałtu w ramach wojny i ludobójstwa. Poza krótkim wprowadzeniem pomijam gwałt jako instytucję w pokojowym trybie funkcjonowania społeczeństw. Interesują mnie tutaj przede wszystkim strategie zbiorowe.

Artykuł mieści się w paradygmacie socjologii historycznej i genocide studies. Przedstawione wnioski oparłem na komparatystyce historycznej przemocy seksualnej w dziesięciu przypadkach wojen i ludobójstw z XX i XXI wieku³. Korzystałem z makroprzyczynowej komparatystyki historycznej (comparative history as macro-causal analysis), którą opisała i stosowała Theda Skocpol ${ }^{4}$, gdzie poprzez stopniowe, systematyczne porównywanie przypadków wyprowadza się teoretyczne generalizacje. W dalszej części wywodu przedstawiam jedynie wyniki badania, czyli pięć typów instytucji gwałtu, pomijając szczegółową analizę poszczególnych zdarzeń.

\section{Gwałt jako przedmiot nauk społecznych}

Gwałt jest przestępstwem odmiennie definiowanym $\mathrm{w}$ różnych aktach prawnych. Penalizuje się także inne czynności seksualne wymuszone na ofierze, nawet jeśli nie doszło do jej penetracji. Na potrzeby tego tekstu zdefiniuję gwałt jako kopulację wymuszoną przemocą lub groźbą przez sprawcę. W przypadku gwałtu zbiorowego mamy do czynienia z przynajmniej dwoma sprawcami. Płeć sprawców i ofiar nie jest zdefiniowana, a zatem można również mówić o gwałcie homoseksualnym. Trzeba pamiętać, że od tego, jakie zachowania w danej kulturze są uważane za seks, zależy, jakie zachowania zostaną uznane za gwałt.

${ }^{2}$ Por. P. Chmielewski: Homo agens. Instytucjonalizm w naukach społecznych. Warszawa 2011.

${ }^{3}$ Przypadki uwzględnione w komparatystyce historycznej instytucji gwałtu (w porządku chronologicznym): 1) ludobójstwo totalne Ormian, imperium osmańskie (1915-1918); 2) masakra w Nankinie dokonana przez armię japońską (1937-1938); 3) ludobójstwo totalne Żydów i Romów popełnione przez Trzecią Rzeszę i sojuszników (1941-1945); 4) niemiecka okupacja ZSRR (1941-1944); 5) ofensywa Armii Czerwonej na terenach Trzeciej Rzeszy w granicach z 1937 roku (1944-1945); 6) pacyfikacja Pakistanu Wschodniego (Bangladeszu) przez armię pakistańską (1971); 7) ludobójstwo częściowe Hutu, Burundi (1972); 8) wojna w Bośni i Hercegowinie (1992-1995); 9) ludobójstwo totalne Tutsi, Rwanda (1994); 10) druga wojna w Demokratycznej Republice Konga (1998-2003).

${ }^{4}$ Th. Skocpol: Social Revolutions in the Modern World. Cambridge 1994, s. 72-92. 
Do tego kulturowo akceptowane formy przymusu nie są postrzegane przez ludzi w danym społeczeństwie jako przemoc seksualna ${ }^{5}$. Interesują mnie zatem najcięższe formy przemocy seksualnej, co jest zrozumiałe, gdy mówimy o wojnach i ludobójstwach. Naturalnie, w czasie tych konfliktów mamy do czynienia także z wymuszaniem innych czynności seksualnych oraz z mniej drastycznymi formami dyskryminacji płciowej.

Gwałt jest przedmiotem kryminologii i kryminalistyki, które ujmują go jako przestępstwo i analizują typy sprawców oraz gwałtów, ich przyczyny, warunki społeczne czynu zabronionego, jak również zasady i sposoby rozpoznawania oraz wykrywania przestępstwa ${ }^{6}$. W przypadku wojen i ludobójstw trzeba też uwzględnić międzynarodowe prawo karne, gdy gwałt ujmuje się jako zbrodnię przeciwko ludzkości albo wręcz zbrodnię ludobójstwa. W socjologii i pokrewnych naukach społecznych gwałt jest analizowany jako patologia społeczna związana z naruszeniem norm i wartości oraz destrukcyjnością zachowania mierzoną skalą potępienia społecznego. W większości przypadków analizuje się jednak indywidualne czyny, które mogą być rozpowszechnione w społeczeństwie, przez co stanowią problem społeczny wymagający przeciwdziałania.

Choć nie zajmuję się w tym artykule analizą prawną, trzeba zaznaczyć, że gwałt jest nie tylko przestępstwem czasów pokoju, ale także wojny. W prawie międzynarodowym nie ma uniwersalnie przyjętej definicji gwałtu, ale penalizuje się różne aspekty przemocy seksualnej. W Rzymskim Statucie Międzynarodowego Trybunału Karnego ${ }^{7}$ wymienia się zbrodnie wojenne, a wśród nich „dopuszczanie się zgwałcenia, niewolnictwa seksualnego, przymusowej prostytucji, wymuszonej ciąży w rozumieniu artykułu 7 ustęp 2 (f), przymusowej sterylizacji oraz innych form przemocy seksualnej również stanowiących poważne naruszenie Konwencji Genewskich"8.

Gwałt jako instytucję analizuje się znacznie rzadziej, co związane jest z tym, że występuje nie tak często, jak indywidualne przestępstwa, a także niejednokrotnie jest tabuizowany $\mathrm{w}$ dyskursie publicznym. W przypadku instytucji gwałtu możemy obserwować geograficzne zróżnicowanie jego form łączące się ze zróżnicowaniem kulturowym poszczególnych regionów. Przykładem może być "gwałt honorowy" będący nieobowiązkową częścią tzw. zbrodni honorowych, gdy kobieta jest karana za zhańbienie rodziny. Na skutek przemocy wymierzonej w kobietę (kończącej się najczęściej śmiercią) rodzina może odzyskać honor,

${ }^{5}$ Por. Ch.L. Muehlenhard, Z.D. Peterson: Konceptualizacja przemocy seksualnej. W: Dobro $i$ zło z perspektywy psychologii społecznej. Red. A.G. Miller. Przeł. V. Reder. Kraków 2008, s. $314,317$.

${ }^{6}$ Por. B. Hołyst: Socjologia kryminalistyczna. T. 1-2. Warszawa 2007 - T. 1, s. 395-401; T. 2, s. 69-79.

7 Rzymski Statut Międzynarodowego Trybunału Karnego sporządzony w Rzymie dnia 17 lipca 1998 r. „Dziennik Ustaw” 2003, nr 78, poz. 708.

8 Tamże, art. 8, ust. 2, pkt b, podpkt xxii. 
który utraciła w wyniku jej pozamałżeńskiej aktywności płciowej. Dotyczy to również sytuacji, gdy kobieta została wcześniej zgwałcona. Instytucja gwałtu honorowego współcześnie jest ściśle związana z tradycyjnym prawem i obyczajowością islamską ${ }^{9}$ Innym przykładem są homoseksualne gwałty więzienne będące częścią subkultury (grypserki), w której zgwałcenie jest formą degradacji więźnia i trwałego zepchnięcia go na dół hierarchii ${ }^{10}$. O jeszcze innej instytucji możemy mówić w ramach niewolnictwa, gdy niewolnica lub niewolnik są wykorzystywani seksualnie lub gwałceni za karę. Przy czym chodzi tu nie o działalność organizacji przestępczych, ale o instytucję niewolnictwa nadal zakorzenioną kulturowo $\mathrm{w}$ wielu regionach świata. Obecnie, jak się szacuje, zniewolonych jest ponad $40 \mathrm{mln}$ ludzi, z czego $1 / 4$ to dzieci. 98\% zniewolonych kobiet doświadczyło przemocy seksualnej ${ }^{11}$. Wymienione instytucje funkcjonują w czasach pokoju, choć wybuch wojny czy ludobójstwa nie prowadzi do ich zaniku. Nowa sytuacja wpływa jednak na transformację tych instytucji. Przykładem może być rozwój instytucji gwałtów w subkulturze więźniów niemieckich obozów koncentracyjnych w czasie drugiej wojny światowej.

Oprócz zróżnicowania geograficznego i kulturowego trzeba też pamiętać o wymiarze diachronicznym. W krajach Globalnej Północy - mimo licznych zastrzeżeń (na przykład rozpowszechnione tzw. mity na temat gwałtu) - funkcjonują obecnie wysokie standardy ochrony wolności seksualnej jednostek. Szczególnej opiece podlegają dzieci - gwałt na nich jest definiowany w wielu krajach jako typ kwalifikowany gwałtu, podobnie jak zgwałcenie zbiorowe czy kazirodcze. Ten stan prawny i świadomość społeczna są jednak stosunkowo niedawnym wytworem społecznym. Przez wieki pewne kategorie społeczne były chronione przed konsekwencjami gwałtu. Wysoko urodzeni mieli zapewnioną bezkarność społeczną, a biedni, służba domowa, dzieci czy kobiety byli często ignorowani przez sędziów ${ }^{12}$. Zmiany mentalności dotyczą także wieku XX. Na przykład w czasie drugiej wojny światowej liczba gwałtów była wysoka, ale tylko nieliczni sprawcy stanęli za nie przed sądem (nikogo nie oskarżono o gwałty w Norymberdze). Analizując gwałty w czasie konfliktów, trzeba zatem uwzględniać również kontekst historyczny.

Dodać też należy, że niektóre paradygmaty w naukach społecznych poświęcają szczególną uwage gwałtowi. Dotyczy to zwłaszcza teorii feministycznych, które wykorzystuję także w tym artykule. Feministki wpłynęły na świadomość

${ }^{9}$ Por. K. Sadowa: Zbrodnie „honorowe” problemem współczesnej Europy? Zarys tematyki. W: Prawo życia i śmierci. Red. M. Sadowski, A. Spychalska, K. Sadowa. Wrocław 2013, s. 209-239.

${ }^{10}$ Zob. P. Moczydłowski: Drugie życie więzienia. Warszawa 2002, s. 115-118, 132-135.

${ }^{11}$ Por. Scourge of Slavery Still Claims 40 Million Victims Worldwide, 'Must Serve as a Wakeup Call'. “UN News”, 9.09.2019. Dostępne w Internecie: https://news.un.org/en/story/2019/09/1045972 [data dostępu: 20.09.2019].

${ }^{12}$ Por. G. Vigarello: Historia gwałtu. Od XVI do XX wieku. Przeł. A. Leyk. Warszawa 2010, s. $31-38,97$. 
zbiorową w poszczególnych krajach i we wspólnocie międzynarodowej. Przemoc seksualna wymierzona nie tylko w kobiety jest dla nich patologią wymagającą pogłębionego opisu ${ }^{13}$.

\section{Gwałt jako instytucja wojenna}

Przemoc seksualna była częścią konfliktów zbrojnych od początków cywilizacji. Żołnierze nie tylko brutalnie grabili cywilów (przede wszystkim w ramach aprowizacji), ale również torturowali ich i gwałcili. Zmiana standardów związana była ze zmianą sztuki wojennej. Masowe armie narodowe w epoce po Wielkiej Rewolucji Francuskiej musiały cechować się o wiele większą karnością. Ukrócenie okrucieństw było zatem przede wszystkim pochodną nowej strategii militarnej, której korzenie sięgają nie tylko tej rewolucji. Stopniowo zmieniały się jednak także postawy społeczne. W wieku XX wszechobecne gwałty wojenne uznawano coraz powszechniej za patologię.

Mimo tych przemian gwałt nadal był traktowany w wielu konfliktach jako nagroda dla żołnierzy, zwłaszcza po zdobyciu długo broniącego się miasta czy przełamaniu trudnego odcinka frontu. To, moim zdaniem, pierwszy typ gwałtu jako instytucji, mający jednocześnie bardzo długą historię społeczną. Instytucja ta była regulowana przez armijną subkulturę, wiedzieli o niej wysocy rangą dowódcy. Oparta była na kulturze tajemnicy i pogardy dla cywilów wroga. W tej wersji instytucja ta przetrwała $\mathrm{w}$ wielu armiach także współcześnie, o czym przekonują konflikty zbrojne w XX wieku (choćby wojna w Wietnamie).

Nie każdy gwałt żołnierski mieści się w ramach tej instytucji, która określa, kiedy żołnierz może złamać twarde zasady dyscypliny. Gwałty takie poddane są regułom, czyli rutynowym działaniom, konwencjom, rolom, strategiom, przekonaniom, kodeksom i technologiom. „Rutynowe działania instytucjonalne są wykonywane nawet wówczas, gdy nie jest oczywiste, czy leży to w wąsko pojętym interesie własnym osoby ponoszącej za nie odpowiedzialność"14 - stwierdzają nowi instytucjonaliści. Tezę tę odnieść można również do instytucji gwałtów wojennych. Odbywały się one za przyzwoleniem żołnierskiej grupy odniesienia, w tym dowódców, nawet jeśli to przyzwolenie polegało na pozostawieniu żołnierzy samych, odwracaniu oczu czy śmiechu. Wiele z tych gwałtów miało

${ }^{13}$ Zob. E. Karen: The Grip of Sexual Violence: Reading United Nations Security Council Resolutions on Human Security. In: Rethinking Peacekeeping, Gender Equality and Collective Security. Eds. G. Heathcote, D. Otto. London 2014, s. 23-47. Por. J. Mizielińska: Płeć, ciało, seksualność. Od feminizmu do teorii queer. Kraków 2006.

${ }^{14}$ J.G. March, J.P. Olsen: Instytucje. Organizacyjne podstawy polityki. Przeł. D. Sielski. Warszawa 2005, s. 32. 
charakter zbiorowy. W imię obrony dyscypliny dowódcy niejednokrotnie ograniczali funkcjonowanie tej instytucji, wprowadzając drakońskie kary. Mogło to zresztą prowadzić do postępującej brutalizacji, jak w przypadku Wehrmachtu na froncie wschodnim. „Żyjąc w strachu przed dowódcami i nie mogąc pokonać nieprzyjaciela, żołnierze niemieccy wyładowywali swą frustrację na ludności cywilnej krajów okupowanych i na jeńcach. [...] Tworzyło się więc błędne koło: wypaczenia dyscypliny skutkowały coraz większym barbarzyństwem, a to z kolei prowadziło do coraz większej brutalizacji dyscypliny”.15. Ten „zorganizowany chaos" paradoksalnie zwiększał spójność Wehrmachtu ${ }^{16}$.

W tym systemie były też (zaplanowane lub nie) wyjątki, których przykładem może być SS-Sondereinheit Dirlewanger, dowodzony przez Oskara Dirlewangera, a złożony między innymi z kłusowników. Członkowie jednostki przeprowadzali tak okrutne pacyfikacje, że w 1941 roku zainteresowały się nią organa wymiaru sprawiedliwości $\mathrm{SS}^{17}$. W zbiorowych gwałtach, także na dzieciach, uczestniczyli również oficerowie ${ }^{18}$. Gwałty były nagrodą, ale też elementem szerokiego repertuaru przemocy stosowanej wobec ofiar. Na marginesie warto dodać, że w Norymberdze nikogo nie oskarżono o gwałt lub podżeganie do takich aktów; mimo podobnej podstawy prawnej niektórzy Japończycy zostali uznani przed trybunałem w Tokio za winnych gwałtu ${ }^{19}$.

Instytucja gwałtu jako nagrody dominowała wśród form przemocy Armii Czerwonej wobec niemieckich kobiet. W pierwszym okresie po jej wkroczeniu na ziemie Trzeciej Rzeszy (w granicach z 1937 roku) dało się zaobserwować liczne akty oddolnej przemocy i żołnierskiej niesubordynacji. Zabijano cywilów, niszczono i grabiono mienie, gwałcono kobiety. Jak napisał we wspomnieniach sowiecki weteran: „Nikt - żaden dowódca czy politruk - nie próbował powstrzymywać żołnierzy. Wiedzieli, że to nie miałoby sensu, że nie da się okiełznać tego gniewu" ${ }^{20}$. Dopiero w późniejszej fazie władze w Moskwie brutalnie przywróciły dyscyplinę. Jak się szacuje, Sowieci zgwałcili około 1,9 mln kobiet podczas radzieckiej ofensywy w latach $1944-1945^{21}$. Gwałcono zarówno dziewczynki, jak i stare kobiety, stosowano tortury i bezczeszczono zwłoki („Widziałem dwie kobiety, z których jedna miała w pochwie stylisko od wideł do siana, a druga drewniany kołek"22).

${ }^{15}$ O. Bartov: Żotnierze Führera. Przeł. J. Skowroński. Warszawa 2004, s. 92-94.

16 Por. tamże, s. 109.

${ }^{17}$ Zob. Ch. Ingrao: Czarni myśliwi. Brygada Dirlewangera. Przeł. W. Gilewski. Wołowiec 2011, s. 18.

${ }_{18}$ Por. tamże, s. 197, 201, 208-209.

19 Por. S.J. Russell-Brown: Rape as an Act of Genocide. "Berkeley Journal of International Law" 2003, Vol. 21, no 2, s. 359-360.

20 B. Gorbaczewski: Przez wojenna zawieruchę. Wojna żotnierza Armii Czerwonej na froncie wschodnim: 1942-1945. Przeł. K. Bażyńska-Chojnacka, P. Chojnacki. Poznań 2011, s. 433.

${ }^{21}$ Por. J. Holzer: Europa wojen 1914-1945. Warszawa 2008, s. 378.

${ }^{22}$ N. Sennerteg: Zemsta Stalina 1944-1945. Przeł. W. Łygaś. Warszawa 2007, s. 313. 
Walka $z$ instytucją gwałtu najczęściej motywowana była pragmatycznie. W przypadku Wehrmachtu rozbudowany system domów publicznych oraz seksualna eksploatacja kobiet $\mathrm{z}$ okupowanych narodów miały przeciwdziałać gwałtom i relacjom żołnierzy z kobietami wroga, które groziły rozprzestrzenianiem się chorób przenoszonych drogą płciową, ale także zdradą tajemnicy wojskowej. W grę wchodziła również „czystość rasowa” i obawa przed „skalaniem”, charakterystyczna dla ideologii nazistowskiej ${ }^{23}$. Dowództwo starało się zatem zastąpić nieformalną instytucję gwałtu jako nagrody formalną instytucją domu publicznego, którego funkcjonowanie można określić jako wykorzystywanie kobiet przy poparciu państwa, w tym takich, które można określić jako niewolnice seksualne. W ramach tej logiki domy publiczne tworzono nawet w obozach koncentracyjnych, chcąc zwiększyć produktywność więźniów ${ }^{24}$. Podobne przykłady znajdujemy także w innych armiach. Na przykład 80-200 tys. kobiet narodowości koreańskiej i innych zmuszonych zostało do niewoli seksualnej w domach publicznych japońskiej armii ${ }^{25}$.

Oczywiście, funkcjonowanie tych instytucji oparte było na pewnym stereotypie mężczyzny jako agresywnego samca, który musi często zaspokajać swoje potrzeby seksualne. $\mathrm{W}$ tej optyce alternatywą dla formalnych instytucji seksualnych okazały się instytucje nieformalne lub samodzielne gwałty i dobrowolne związki z kobietami z okupowanych terytoriów. Naziści obawiali się także aktów homoseksualnych, które mogłyby się rozprzestrzenić w armii. Stereotyp ten był podstawą ideologii panującej w większości wojsk, a podtrzymywali go nie tylko dowódcy, ale również żołnierze. W Trzeciej Rzeszy naziści ustanowili zresztą silnie mizoginiczny system (można mówić zarówno o rasistowskim seksizmie, jak i seksistowskim rasizmie ${ }^{26}$ ), co jednak nie oznaczało, że kobiety nie były sprawczyniami ludobójstwa i nie angażowały się w szerzenie nazistowskich idei ${ }^{27}$.

${ }^{23}$ Por. R. Mühlhäuser: Between 'Racial Awareness' and Fantasies of Potency: Nazi Sexual Politics in the Occupied Territories of the Soviet Union, 1942-1945. In: Brutality and Desire. War and Sexuality in Europe's Twentieth Century. Ed. D. Herzog. New York 2009, s. 197-220.

${ }^{24}$ Por. J. Ostrowska: Przemilczane. Seksualna praca przymusowa w czasie II wojny światowej. Warszawa 2018.

${ }^{25}$ Por. G. McCormack: Reflections on Modern Japanese History in the Context of the Concept of Genocide. In: The Specter of Genocide. Mass Murder in Historical Perspective. Eds. R. Gellately, B. Kiernan. Cambridge 2003, s. 279-280; I. Chang: Rzeź Nankinu. Przeł. K. Godlewski. Warszawa 2013, s. 67.

${ }^{26}$ Por. J. Stöcker-Sobelman: Kobiety Holokaustu. Feministyczna perspektywa w badaniach nad Shoah. Kazus KL Auschwitz-Birkenau. Warszawa 2012, s. 85.

${ }_{27}$ Zob. Ch. Herkommer: Women under National Socialism: Women's Scope for Action and the Issue of Gender. In: Ordinary People as Mass Murderers: Perpetrators in Comparative Perspective. Eds. O. Jensen, C.-Ch.W. Szejnmann. Houndmills, Basingstoke, Hampshire 2008, s. 106-107; I. Heike: Female Concentration Camp Guards as Perpetrators: Three Case Studies. In: Ordinary People as Mass Murderers..., s. 120-142. 
Rozważania te prowadzą nas do drugiej instytucji gwałtu, najczęściej zbiorowego, która miała na celu wzmacnianie relacji w grupie żołnierskiej i dowodzenie przez żołnierzy swej męskości. Instytucja ta mogła się nakładać na instytucję gwałtu jako nagrody, ale funkcjonowała niezależnie, także wtedy, gdy żołnierze łamali rozkazy i naruszali dyscyplinę. Kolega z oddziału nie mógł zrezygnować z udziału w gwałcie. Nie tylko dlatego, że jako współwinny gwarantował w oczach pozostałych żołnierzy zachowanie tajemnicy. Musiał potwierdzać swą nieustanną gotowość do penetracji kobiety. Dla młodych żołnierzy były to często formy inicjacji zapewniającej im wspólnotę z oddziałem. Wiele relacji pokazuje, że gwałty takie postrzegane były jako przymus, od którego żołnierze, chcąc zadowolić kolegów, nie mogli się uchylić. Kobieta była medium komunikacji między nimi ${ }^{28}$, gwałt zaś stanowił zadanie do wykonania, a nie proste zaspokojenie potrzeb żołnierza.

Gwałt stawał się również instytucją ofensywną w konflikcie, gdy przywódcy polityczni i dowódcy uznawali, że dzięki temu mogą uderzyć w obcą grupę. To środek symbolicznego ataku, gdyż zgwałcone kobiety zostają „skalane”, a „ich” mężczyźni pozbawieni honoru. Ta logika jest oczywiście ściśle związana z kontekstem kulturowym, ale funkcjonuje w większości społeczeństw patriarchalnych. W pewnych krajach może działać silniej, w innych słabiej, ale zasadniczo jest bardzo destrukcyjna.

Z funkcją symboliczną powiązana jest funkcja pragmatyczna - obarczenie wrogiej grupy koniecznością urodzenia i wychowania dzieci gwałcicieli. Podobnie jak „pozbawienie honoru” niszczy to morale wroga. Obciąża go także finansowo - to mechanizm zbliżony do działania min lądowych, które nie zabijają, ale okaleczają żołnierzy, leczonych potem i utrzymywanych przez społeczeństwo, z którym toczy się wojnę. Zgwałcone kobiety wymagają pomocy lekarskiej, niejednokrotnie chcą przeprowadzić aborcję, co może być dla nich kolejnym obciążeniem psychicznym; dzieci zaś, których poczęcie wynikało z gwałtu, często są niekochane i postrzegane jako obce. Gwałt wojenny działa podobnie jak mina przeciwpiechotna - rwie więzi społeczne, ale (najczęściej) nie zabija.

Ten typ instytucji gwałtu występował nie tylko w konfliktach międzynarodowych, ale także w wojnach domowych i pacyfikacjach zbuntowanych prowincji. Wtedy masowe gwałty służą ukaraniu zbuntowanej społeczności, są formą zemsty. W czasie konfliktu w Pakistanie Wschodnim w 1971 roku (dzisiejszy Bangladesz) żołnierze pakistańscy zgwałcili około 200 tys. kobiet i dziewczą ${ }^{29}$.

Masowe gwałty często łączą wymienione typy instytucji. Tak było w przypadku masakry nankińskiej (13 grudnia 1937 roku-styczeń 1938 roku) w czasie wojny chińsko-japońskiej. Jak się powszechnie szacuje, żołnierze armii japońskiej

\footnotetext{
28 Zob. C. Card: Rape as a Weapon of War. "Hypatia” 1996, Vol. 11, no 4, s. 6.

29 Por. O.B. Jones: Pakistan. Oko cyklonu. Przeł. M. Żytomirski. Warszawa 2005.
} 
zgwałcili wtedy 20 tys. kobiet i dziewcząt ${ }^{30}$. Gwałty były najczęściej zbiorowe, ich ofiarą padały także małe dziewczynki. Iris Chang w swojej głośnej książce opisała bardzo transgresyjne formy gwałtów - według niej ofiary zmuszano do kazirodztwa, gwałty połączone były z torturami i kończyły się mordem, gwałcono również mężczyzn ${ }^{31}$. Wywód autorki budzi jednak poważne zastrzeżenia metodologiczne i źródłowe. Okrucieństwo związane było z frustracją żołnierzy japońskich, którzy nie spodziewali się w tej wojnie skutecznego oporu ze strony Chińczyków postrzeganych jako „łatwi do pokonania tchórze”; trzeba też pamiętać, że do ostatniej chwili przygotowywali się oni do obrony Nankinu ${ }^{32}$. Nie było to ani złamanie dyscypliny, brutalnie karane w armii japońskiej, ani ludobójcza rzeź. Co najmniej do lutego 1938 roku nie da się znaleźć żadnych śladów interwencji władzy centralnej, oficerowie zaś odznaczali się „skrajną pobłażliwością wobec zbrodni popełnianych na cywilach" ${ }^{33}$. W większości przypadków, jak się zdaje, dominowała instytucja gwałtu jako nagrody, gdy japońscy żołnierze wykorzystywali kobiety do posług, a potem gwałcili ${ }^{34}$.

Współcześnie instytucje gwałtu mają szeroki zasięg, zwłaszcza w ramach tzw. nowych wojen. Walczy w nich wielu niepaństwowych aktorów („prywatyzacja” wojny), w tym warlordowie ${ }^{35}$. Konflikty te charakteryzują się „asymetryzacją przemocy wojennej", tzn. z reguły walczą ze sobą nierówni przeciwnicy. Skutkuje to partyzanckimi i terrorystycznymi metodami prowadzenia wojen. Następuje w nich ,autonomizacja form przemocy”, które wcześniej podporządkowane były militarnej strategii. Związana jest $\mathrm{z}$ nimi nowa ekonomia - prowadzenie tych wojen opłaca się, między innymi dzięki rabunkowi surowców naturalnych, handlowi narkotykami i ludźmi. Rośnie w nich także udział najemników ${ }^{36}$. W wojnach tych dochodzi również do „reseksualizacji przemocy”. „W nowych wojnach natomiast, które akurat pod tym względem przedstawiają powrót do późnośredniowiecznych form prowadzenia wojny, gwałty są nieraz wysoce funkcjonalne: podkopują gotowość wytrwania w kraju przodków pomimo trudnych warunków i codziennego zagrożenia życia w oczekiwaniu na lepsze czasy"37. Przykładem takiego konfliktu jest zwłaszcza druga wojna w Demokratycznej Republice Konga (1998-2003). Setki tysięcy kobiet i dziewcząt zostało zgwałconych, stosowano także takie formy przemocy, jak seksualne niewolnictwo

${ }^{30}$ Por. J.-L. Margolin: Japonia 1937-1945. Wojna Armii Cesarza. Przeł. J.P. Rurarz, A. Rurarz. Warszawa 2009, s. 212.

${ }^{31}$ Zob. I. Chang: Rzeź Nankinu..., s. 106-113.

${ }^{32}$ Zob. J.-L. Margolin: Japonia 1937-1945..., s. 190, 197.

${ }^{33}$ Tamże, s. 225-226.

34 Por. tamże, s. 212-213.

${ }_{35}$ Por. H. Münkler: Wojny naszych czasów. Przeł. K. Matuszek. Kraków 2004.

${ }^{36}$ Por. R. Uesseler: Wojna jako ustuga. Jak prywatne firmy wojskowe niszcza demokrację. Przeł. M. Kalata. Warszawa 2008.

${ }^{37}$ H. Münkler: Wojny naszych czasów..., s. 109. 
i przymusowe małżeństwa ${ }^{38}$. Żołnierze byli chronieni przez dowódców, również po zakończeniu wojny ${ }^{39}$. Masowe gwałty były wykorzystywane jako element kary wobec ludności i służyły do jej zastraszania oraz kontrolowania ${ }^{40}$.

\section{Instytucja gwałtu w czystkach etnicznych i ludobójstwach}

Wymienione już funkcje gwałtu jako instytucji ofensywnej zyskują na znaczeniu w ramach takich projektów społecznych, jak czystka etniczna. W ich przypadku masowe gwałty są „inwestycją” $\mathrm{w}$ konflikt. W połączeniu $\mathrm{z}$ masakrami i torturami mają pomóc osiągnąć główny cel - ucieczkę przerażonych ludzi ze spornego terytorium. Każde ludobójstwo jest czystką etniczną, ale nie każda czystka etniczna jest ludobójstwem. Celem sprawców jest „oczyszczenie” spornego terytorium z ludności wroga. Może to przybrać formę legalnych w świetle prawa międzynarodowego przymusowych przesiedleń ludności (na przykład Niemców po drugiej wojnie światowej), nielegalnych wypędzeń z wykorzystaniem nacisków społecznych (prawnych, ekonomicznych i społecznych) albo brutalnych wypędzeń przy użyciu przemocy. $\mathrm{W}$ tym ostatnim przypadku członkowie wrogiej społeczności mogą być mordowani, ale celem sprawców nie jest eksterminacja całej grupy, tylko przejęcie terytorium.

Często przywoływanym przykładem jest wojna w byłej Jugosławii - która zresztą sprawiła, że termin "czystka etniczna” się upowszechnił - a zwłaszcza wojna w Bośni i Hercegowinie. Wszystkie strony konfliktu (Serbowie, Chorwaci, Boszniacy) stosowały wobec siebie przemoc i zakładały obozy koncentracyjne, ale to Boszniaczki padły ofiarą masowych gwałtów ze strony serbskiej armii i grup paramilitarnych ${ }^{41}$. „Gwałcenie kobiet bośniackich było narzędziem terroru stosowanym wobec ludności muzułmańskiej, elementem czystki etnicznej w Bośni”"42. Czasami gwałt zastępowały seksualne tortury lub molestowanie, zwłaszcza gdy

${ }^{38}$ Por. S. Meger: Rape of the Congo: Understanding Sexual Violence in the Conflict in the Democratic Republic of Congo. "Journal of Contemporary African Studies" 2010, Vol. 28, no 2, s. 119.

${ }^{39}$ Zob. Soldiers Who Rape, Commanders Who Condone. Sexual Violence and Military Reform in the Democratic Republic of Congo. New York 2009, s. 5.

${ }^{40}$ Zob. U. Róg: Przemoc seksualna we wschodniej części Demokratycznej Republiki Konga. Zarys problemu. W: Kobiety wojny. Między zbrodnią a krzykiem o godność. Red. A. Bartuś. Oświęcim 2014, s. 94, 96.

${ }^{41}$ Por. E. Markusen: Genocide in Bosnia. In: Teaching about Genocide: Issues, Approaches, and Resources. Ed. S. Totten. Greenwich 2004, s. 197.

${ }^{42}$ S. Drakulić: Oni nie skrzywdziliby nawet muchy. Zbrodniarze wojenni przed Trybunałem w Hadze. Przeł. J. Szacki. Warszawa 2006, s. 69. 
sprawcy byli zbyt pijani ${ }^{43}$. Boszniacy jako muzułmanie zajmowali szczególne miejsce w serbskiej i chorwackiej nacjonalistycznej historiografii, walkę z nimi przedstawiano jako obronę przed ustanowieniem państwa islamskiego ${ }^{44}$. Według szacunków rządu bośniackiego zgwałconych zostało około 60 tys. kobiet ${ }^{45}$.

Wojna w Bośni i Hercegowinie cechowała się patologiami typowymi dla wojny domowej. Po stronie serbskiej oprócz armii Republiki Serbskiej brało udział wiele organizacji paramilitarnych, w tym złożonych z kibiców piłkarskich i przestępców, jak „Tygrysy Arkana” (Željko Ražnatovića ${ }^{46}$ ). Byli oni nie tylko mniej zdyscyplinowani, ale także skorzy do przemocy. Korzystali również z „kultury bezkarności”, sądząc, że mogą zrobić wszystko, co wymyśląa ${ }^{47}$. Zbiorowe publiczne gwałty przypominały postępowanie gangów. Były bez wątpienia nagrodą i sposobem na potwierdzenie swej męskości, ale dominowała nienawiść do wroga, którego należy ukarać i przepędzić. Gwałt integrował sprawców i odróżniał ich od byłych sąsiadów oraz przyjaciół z obcej grupy narodowościowej ${ }^{48}$. Potwierdzeniem męskości - w oczach kolegów z oddziału - był zwłaszcza udział w walce i zabijanie innych mężczyzn ${ }^{49}$.

Podobieństwo do gangów nie jest incydentalne. Przemoc seksualna w wielu tego typu grupach także regulowana jest nieformalnymi zasadami i można ją uznać za instytucję. W warunkach wojny domowej struktura walczących ma kluczowe znaczenie. Armia ze względów strategicznych wymusza większą dyscyplinę niż paramilitarne oddziały. Może to sprzyjać większej kontroli instytucji gwałtów. W czystkach etnicznych i ludobójstwach ta karność ma jednak destrukcyjne skutki, gdy żołnierze wykonują rozkazy lub zalecenia polityków, stosując przemoc seksualną jako narzędzie wojny. Tak było w Bośni i Hercegowinie. Kobiety żyły przerażone możliwością zgwałcenia, mężczyźni zaś groźbą „pohańbienia” ich żon i córek ${ }^{50}$.

Boszniaczki były gwałcone, ale nie mordowane. Tym samym sprawcy liczyli nie tylko na efekt odstraszający, zmuszający Boszniaków do ucieczki ze spornego terytorium, ale również brali pod uwagę symboliczne i pragmatyczne szkody, jakie wyrządzą wrogiej grupie. Kobiety te atakowano jednocześnie jako kobiety

${ }^{43}$ Por. S. Leydesdorff: Surviving the Bosnian Genocide. The Women of Srebrenica Speak. Transl. K. Richardson. Bloomington-Indianapolis 2011, s. 166.

${ }^{44}$ Por. T. Bringa: Averted Gaze: Genocide in Bosnia-Herzegovina, 1992-1995. In: Annihilating Difference. The Anthropology of Genocide. Ed. A.L. Hinton. Berkeley-Los Angeles-London 2002, s. 215.

${ }^{45}$ Zob. S. Drakulić: Oni nie skrzywdziliby nawet muchy..., s. 68.

${ }^{46}$ Zob. E. Markusen: Genocide in Bosnia..., s. 195.

${ }^{47}$ Por. J. Sémelin: Analysis of Mass Crime. Ethnic Cleansing in the Former Yugoslavia 19911999. In: The Specter of Genocide..., s. 365.

${ }^{48}$ Por. C. Card: Rape as a Weapon of War..., s. 7.

${ }^{49}$ Zob. M. Mann: The Dark Side of Democracy. Explaining Ethnic Cleansing. Cambridge 2006, s. 420-421.

${ }^{50}$ Zob. S. Leydesdorff: Surviving the Bosnian Genocide..., s. 22. 
właśnie i jako Boszniaczki. Tym samym instytucja gwałtu w czystkach etnicznych wykazuje wiele podobieństw do instytucji gwałtu ofensywnego, opisanego przeze mnie wcześniej.

Gwałty w czasie ludobójstw rządziły się podobnymi zasadami, jak podczas wojen i czystek etnicznych, tyle że ofiary później mordowano. Na przykład deportacyjne „marsze śmierci” Ormian były napadane, ofiary okradano, kobiety gwałcono, a dzieci porywano i oddawano do tureckich sierocińców. Ofiary, które przeżyły deportacje, umierały na pustyni ${ }^{51}$. Zdarzały się też różne ekscesy, w tym gwałty na dzieciach ${ }^{52}$. Czy można zatem uznać, że istnieje ludobójcza instytucja gwałtu? Aby odpowiedzieć na to pytanie, trzeba przyjrzeć się ludobójstwu w Rwandzie w 1994 roku.

Przemoc seksualna wobec kobiet Tutsi (ale także kobiet Hutu związanych z mężczyznami Tutsi) była ważnym wymiarem ludobójstwa. Jak ustalił Międzynarodowy Trybunał Karny dla Rwandy (International Criminal Tribunal for Rwanda, ICTR), wiele gwałtów popełniano z zamiarem późniejszego zabicia kobiet. Dokonywano ich również w pobliżu masowych grobów. Gwałty miały na celu zwiększenie cierpienia kobiet Tutsi, skazanych na zagładę w ramach ludobójczego planu ${ }^{53}$. Utworzono wówczas specjalne oddziały gwałcicieli złożone z mężczyzn chorych na AIDS, w tym zwolnionych ze szpitali ${ }^{54}$. Kobiety były torturowane i okaleczane, sprawcy pastwili się zwłaszcza nad ich narządami płciowymi.

Kobiety Tutsi postrzegano - zgodnie z ideologiczną definicją - jako bardziej atrakcyjne od kobiet Hutu, ale przede wszystkim uważano, że wychodzą za mężczyzn Hutu, aby ich omotać i szpiegować. „Twój wróg to Tutsi, ale twój największy wróg to kobieta Tutsi” ${ }^{\prime 25}$ - głoszono. Te wyobrażenia określały także formy przemocy. „I jeszcze krzyk mojej kuzynki. Nie była zbyt ładna, więc ją zgwałcili od razu. Pniem bananowca. Zaostrzonym przez kobiety Hutu, które stały obok"56.

Gwałt jako narzędzie ludobójstwa rozważano w sprawie przeciwko Jean-Paulowi Akayesu. Od kwietnia 1993 roku do czerwca 1994 roku był burmistrzem wspólnoty Taba w prefekturze Gitarama. Wcześniej pracował jako nauczyciel i inspektor szkolny. W czasie ludobójstwa nadzorował mordy. We wspólnocie zabito około 2 tys. Tutsi, a tamtejsze kobiety były regularnie gwałcone i pod-

${ }^{51}$ Por. Y. Ternon: Ormianie. Historia zapomnianego ludobójstwa. Przeł. W. Brzozowski. Kraków 2005, s. 246.

52 Por. V.N. Dadrian: Children as Victims of Genocide: the Armenian Case. "Journal of Genocide Research" 2003, Vol. 5, no 3, s. 429.

${ }^{53}$ Por. Case No. ICTR-96-4-T. Prosecutor v. Jean-Paul Akayesu. Judgement. International Criminal Tribunal for Rwanda. 1 June 2001, punkt 733.

54 Zob. S.J. Russell-Brown: Rape as an Act of Genocide..., s. 354; J. Reginia-Zacharski: Rwanda. Wojna i ludobójstwo. Warszawa 2012, s. 127.

55 W. Tochman: Dzisiaj narysujemy śmierć. Wołowiec 2010, s. 48.

56 Tamże, s. 64. 
dawane innym formom przemocy seksualnej ${ }^{57}$. W ramach procesu Akayesu Trybunał zdefiniował gwałt jako fizyczną napaść o charakterze seksualnym, popełnioną na osobie w okolicznościach, które są przymusowe, co nie oznacza konieczności użycia przemocy fizycznej ${ }^{58}$. Uznano, że gwałt i przemoc seksualna mogą sprowadzać się do ludobójstwa, gdy popełniane są z zamiarem zniszczenia lub częściowego zniszczenia określonej grupy ${ }^{59}$. Akayesu skazano jednak za gwałt jako zbrodnię przeciwko ludzkości.

W kontekście przemocy seksualnej szeroko znane stało się nazwisko Pauline Nyiramasuhuko, byłej minister ds. rodziny i rozwoju kobiet. W czasie ludobójstwa współkierowała masakrami w prowincji Butare. Jest pierwszą kobietą oskarżoną przed Międzynarodowym Trybunałem Karnym dla Rwandy oraz pierwszą kobietą w historii oskarżoną o gwałt jako zbrodnię przeciwko ludzkości. Ostateczny werdykt w apelacji zapadł 14 grudnia 2015 roku. Proces w sumie trwał czternaście lat. Nyiramasuhuko skazano między innymi za podżeganie do gwałtów; nakłoniła do nich także swojego syna, Arsène’a Shaloma Ntahobali ${ }^{60}$.

Gwałt można uznać za instytucję we wcześniejszym ludobójstwie częściowym w Burundi. Zaczęło się ono od krwawego zdławienia powstania chłopskiego (które wybuchło 29 kwietnia 1972 roku). Frank Chalk i Kurt Jonassohn określili je mianem „Holokaustu w Burundi”"61. W czasie kilkumiesięcznej pacyfikacji zginęło 200-300 tys. cywilów, w tym kobiety i dzieci zabijane ze szczególnym okrucieństwem ${ }^{62}$. Dodajmy, że wcześniej powstańcy Hutu z równym okrucieństwem mordowali Tutsi (zginęło 2-5 tys. cywilów). W odwecie władze zaplanowały i przeprowadziły mord, a dokonały go rękami armii, policji, administracji oraz zwykłych obywateli. Co szczególne, to ludobójstwo częściowe, choć związane było z niedyskryminacyjnym zabijaniem mężczyzn, kobiet i dzieci, miało wiele cech elitobójstwa. Tutsi postanowili bowiem wyeliminować wszystkich wyedukowanych Hutu, w tym uczniów szkół średnich. Systematycznie i konsekwentnie mordowano oficerów oraz żołnierzy Hutu w armii. Ludobójstwo częściowe dokonane na Hutu miało bez wątpienia wiele cech krwawej pacyfikacji. Jednocześnie wyraźna jest tu intencja wymordowania części populacji w celu podważenia jej statusu. Przy okazji oficerowie Tutsi postanowili zabić obalonego króla Ntare, oskarżonego o działanie na szkodę rządu - chciano w ten sposób przeciwdziałać możliwości odrodzenia się monarchii.

${ }^{57}$ Por. S.J. Russell-Brown: Rape as an Act of Genocide..., s. 368.

${ }^{58}$ Zob. Case No. ICTR-96-4-T. Prosecutor v. Jean-Paul Akayesu. Judgement. International Criminal Tribunal for Rwanda. 1 June 2001, punkt 688.

${ }^{59}$ Por. tamże, punkt 731.

${ }^{60}$ Por. Case No. ICTR-98-42-T. Prosecutor v. Nyiramasuhuko et al. Judgement and sentence. International Criminal Tribunal for Rwanda. 24 June 2011.

${ }^{61}$ F. Chalk, K. Jonassohn: The History and Sociology of Genocide. Analyses and Case Studies. New Haven-London 1990, s. 384.

${ }^{62}$ Por. R. Lemarchand: The Burundi Genocide. In: Teaching about Genocide..., s. 155. 
Mordowanie Hutu miało barbarzyński charakter. Nabijano na pal mężczyzn i kobiety, wycinano płody $z$ brzuchów ciężarnych matek, zmuszano rodziców do zjedzenia mięsa ich dzieci oraz do kazirodczych stosunków ${ }^{63}$. Można się w tych krwawych aktach dopatrywać zarówno realizacji szczególnych wzorów kulturowych, mających niejednokrotnie magiczne uzasadnienie, jak i racjonalnej intencji zastraszenia zbuntowanej ludności, aby w przyszłości nie odważyła się podważać dominacji Tutsi.

W regionie Wielkich Jezior nie można jednak ograniczać zjawiska gwałtów do czasu wojny i trzymać się sztywnych podziałów etnicznych. W Rwandzie kobiety Hutu gwałcone były nie tylko przez żołnierzy Tutsi, ale też przez członków milicji Hutu. Również w Burundi gwałcono zarówno kobiety Hutu, jak i Tutsi (a także młodych mężczyzn, co jest silnie tabuizowane w Afryce). Zakończenie kolejnych konfliktów nie powstrzymało fali gwałtów, zwłaszcza ze strony mężczyzn w mundurach ${ }^{64}$.

Niezależnie od ustaleń trybunałów karnych zgodzić się trzeba, że w projektach ludobójczych przemoc seksualna może osiągnąć masową skalę i nie jest to tylko kwestia statystyki. W Rwandzie w 1994 roku gwałtu używano przede wszystkim jako instytucji ofensywnej, gdy sprawcy byli wzywani, a nawet dostawali rozkazy, aby gwałcić kobiety Tutsi ${ }^{65}$. Gwałt był przede wszystkim torturą, a nie źródłem przyjemności dla sprawców. Służył symbolicznemu poniżeniu całej grupy Tutsi, kobiet Tutsi jako takich w szczególności, a konkretnych ofiar dopiero w dalszej kolejności. Jednocześnie, podobnie jak mężczyzn okaleczano maczetami i skazywano na powolne konanie, kobiety były gwałcone i okaleczane lub celowo zarażane wirusem HIV, aby ich śmierć poprzedzona była cierpieniem. Ludobójcza rama sprawiała, że gwałt zyskiwał na brutalności, celem była bowiem eksterminacja kobiet Tutsi, a nie zmuszenie ich do wychowywania dziecka poczętego w wyniku gwałtu ${ }^{66}$.

\section{Podsumowanie i wnioski}

W artykule omówiono pięć nieformalnych instytucji gwałtu:

1. Gwałt jako nagroda dla żołnierzy i innych bojowników.

${ }^{63}$ Zob. Ch. Taylor: The Cultural Face of Terror in the Rwandan Genocide of 1994. In: Annihilating Difference..., s. 140-141.

${ }^{64}$ Por. P.O. Daley: Gender and Genocide in Burundi: The Search for Spaces of Peace in the Great Lakes Region. Bloomington 2008, s. 126-127.

${ }_{65}$ Por. A. Jones: Gender and Genocide in Rwanda. In: Gendercide and Genocide. Ed. A. Jones. Nashville 2004, s. 118-120.

${ }^{66}$ Por. S.J. Russell-Brown: Rape as an Act of Genocide..., s. 355-356, 371. 
2. Gwałt jako mechanizm inicjacji żołnierzy, integracji grupy zbrojnej oraz dowodzenia męskości przez walczących.

3. Gwałt jako instytucja ofensywna, mająca dwie główne funkcje:

(3.1.) symbolicznego ataku na grupę obcą oraz (3.2.) zwiększenia kosztów grupy obcej (leczenia kobiet, wychowania niechcianych dzieci itd.). Oba przypadki można uznać za atak na morale wroga.

4. Gwałt jako mechanizm czystki etnicznej.

5. Gwałt jako mechanizm ludobójstwa.

Instytucje te mogą współwystępować w trakcie wojen, a także czystek etnicznych i ludobójstw, przy czym dwa ostatnie typy wykluczają się ze względu na cel sprawców. Są to oczywiście instytucje ofensywne, jak trzeci typ, ale makrospoleczna rama radykalnie zmienia zachowania sprawców.

Wymienione typy dotyczą instytucji, a zatem mamy do czynienia z kulturowo ustanowionymi wartościami i normami, które określają akceptowane cele oraz sposoby ich osiągania. Nie chodzi przy tym najczęściej o powszechną akceptację tych instytucji, ale ich osadzenie w subkulturze określonych organizacji (armii, policji, bojówek partyjnych itd.). Sprawcy mogą zdawać sobie sprawę, że naruszają wartości i normy obowiązujące w społeczeństwie poza grupą odniesienia ${ }^{67}$. Nie każdy gwałt dokonany przez żołnierza należy do wymienionych instytucji. W tym sensie gwałty mogą być postrzegane przez członków danej organizacji jako uprawnione lub nieuprawnione.

Wbrew stereotypom zgwałcenie $w$ ramach tych instytucji nie oznacza z definicji zaspokojenia potrzeby sprawcy. Znacznie częściej czuje się on zobowiązany do gwałtu z powodu presji kolegów, innych żołnierzy czy dowódców - nawet jeśli jest zmęczony zabijaniem i nie ma ochoty na seks ${ }^{68}$. Gwałt $\mathrm{w}$ wielu przypadkach staje się torturą, a nie po prostu praktyką seksualną. Wybór sfery seksualności jako celu ataku wiąże się między innymi z tym, że jest ona traktowana jako istotna dla tożsamości ludzi oraz otacza ją wiele nakazów i zakazów. Tym samym przemoc seksualna zwiększa symboliczną moc napaści, potęgując cierpienia psychiczne bezpośredniej ofiary, jej rodziny i innych członków atakowanej grupy.

Najczęściej instytucje gwałtu dotyczą mężczyzn jako sprawców i kobiet jako ofiar. Ale zdarzają się też liczne wyjątki od tej reguły. Gwałty homoseksualne najczęściej nie są ekspresją potrzeb sprawców, ale szczególnie dotkliwą torturą, nawiązującą do heteronormatywnych kodów kulturowych, wedle których raz zgwałcony mężczyzna nieodwołalnie „traci męskość" (podobnie jak w subkulturze więziennej). Pokazują one wyraźnie, jak przemożny może być wpływ instytucji na działania aktorów w konfliktach. Przemoc wobec kobiet sprawiła, że wprowadzono nowy termin - genderobójstwo (gendercide). Choć kobiety

\footnotetext{
${ }^{67}$ Zob. S. Meger: Rape of the Congo..., s. 132.

${ }^{68}$ Zob. S.J. Russell-Brown: Rape as an Act of Genocide..., s. 353.
} 
często stają się ofiarami przemocy seksualnej, to jednak mężczyźni niebędący żołnierzami są najczęściej ofiarami masowych morderstw w czasie konfliktów ${ }^{69}$.

Gwałty postrzega się jako patologię, która szkodzi społeczności sprawców. Ale, jak pokazano wcześniej, instytucje gwałtu mogą być „funkcjonalne” i służyć celom grupowym - zwiększać integrację oddziałów, przyspieszać ucieczkę ludności w czasie czystki etnicznej czy obniżać morale wroga. W historii walczono z gwałtami, odwołując się często do konkurencyjnych, pragmatycznych celów, na przykład dbając o zdrowie żołnierzy, aby nie trzeba było ich wycofywać $\mathrm{z}$ walki. W przypadku instytucji gwałtu można mówić o „zależności od szlaku” (path dependence), gdy kolejne pokolenia przejmują wyobrażenia poprzedników, kształtując swoje strategie działania. To przekleństwo przeszłości widać wyraźnie na przykład w wielu regionach Afryki Subsaharyjskiej.

Kluczowe znaczenie ma to, że większość ludobójstw i znaczna część czystek etnicznych powiązane są z wojną (rozgrywają się w czasie wojny, bezpośrednio po jej zakończeniu itd.). Tym samym wojenne ramy wpływają na postrzeganie relacji międzyludzkich w czasie aktów zbiorowej przemocy ${ }^{70}$. Instytucje gwałtu wojennego można zatem łatwo wykorzystać $w$ ramach przemocy wymierzonej w ofiary ludobójstwa. Zależność ta jest także fundamentem sprowadzenia instytucji gwałtu w czasie wojen i ludobójstw do wspólnej analitycznej podstawy.

Walka z instytucjami gwałtu wymaga wieloaspektowej polityki - egzekwowania norm prawnych, odpowiedniego kształcenia oficerów i żołnierzy, ale też powszechnej edukacji, która utrudni wyłączanie ofiar z uniwersum moralnych zobowiązań. Wymaga również przemyślenia praw kobiet i dzieci, które są bardzo rozmaicie postrzegane w kulturach patriarchalnych. Kary wymierzone sprawcom przed trybunałami i sądami są ważne, ale nie zastąpią stopniowej zmiany świadomości, bez której subkulturowe instytucje gwałtu nadal mogą z normalnych bojowników uczynić brutalnych gwałcicieli.

\section{Bibliografia}

Bartov O.: Żołnierze Führera. Przeł. J. Skowroński. Warszawa 2004.

Bringa T.: Averted Gaze: Genocide in Bosnia-Herzegovina, 1992-1995. In: Annihilating

Difference. The Anthropology of Genocide. Ed. A.L. Hinton. Berkeley-Los AngelesLondon 2002, s. 194-225.

Buss D.: Psychologia ewolucyjna. Przeł. M. Orski. Gdańsk 2001.

Card C.: Rape as a Weapon of War. "Hypatia" 1996, Vol. 11, no 4, s. 5-18.

${ }^{69}$ Por. A. Jones: Gendercide and Genocide. In: Gendercide and Genocide..., s. 3.

${ }^{70}$ Por. M. Shaw: The General Hybridity of War and Genocide. "Journal of Genocide Research" 2007, Vol. 9, Issue 3, s. 461-473. 
Case No. ICTR-96-4-T. Prosecutor v. Jean-Paul Akayesu. Judgement. International Criminal Tribunal for Rwanda. 1 June 2001.

Case No. ICTR-98-42-T. Prosecutor v. Nyiramasuhuko et al. Judgement and sentence. International Criminal Tribunal for Rwanda. 24 June 2011.

Chalk F., Jonassohn K.: The History and Sociology of Genocide. Analyses and Case Studies. New Haven-London 1990.

Chang I.: Rzeź Nankinu. Przeł. K. Godlewski. Warszawa 2013.

Chmielewski P.: Homo agens. Instytucjonalizm w naukach społecznych. Warszawa 2011.

Dadrian V.N.: Children as Victims of Genocide: the Armenian Case. "Journal of Genocide Research" 2003, Vol. 5, no 3, s. 421-437.

Daley P.O.: Gender and Genocide in Burundi: The Search for Spaces of Peace in the Great Lakes Region. Bloomington 2008.

Drakulić S.: Oni nie skrzywdziliby nawet muchy. Zbrodniarze wojenni przed Trybunałem w Hadze. Przeł. J. Szacki. Warszawa 2006.

Gorbaczewski B.: Przez wojenna zawieruchę. Wojna żołnierza Armii Czerwonej na froncie wschodnim: 1942-1945. Przeł. K. Bażyńska-Chojnacka, P. Chojnacki. Poznań 2011.

Heike I.: Female Concentration Camp Guards as Perpetrators: Three Case Studies. In: Ordinary People as Mass Murderers: Perpetrators in Comparative Perspective. Eds. O. Jensen, C.-Ch.W. Szejnmann. Houndmills, Basingstoke, Hampshire 2008, s. $120-142$.

Herkommer Ch.: Women under National Socialism: Women's Scope for Action and the Issue of Gender. In: Ordinary People as Mass Murderers: Perpetrators in Comparative Perspective. Eds. O. Jensen, C.-Ch.W. Szejnmann. Houndmills, Basingstoke, Hampshire 2008, s. 99-119.

Holzer J.: Europa wojen 1914-1945. Warszawa 2008.

Hołyst B.: Socjologia kryminalistyczna. T. 1-2. Warszawa 2007.

Ingrao Ch.: Czarni myśliwi. Brygada Dirlewangera. Przeł. W. Gilewski. Wołowiec 2011.

Jones A.: Gender and Genocide in Rwanda. In: Gendercide and Genocide. Ed. A. Jones. Nashville 2004, s. 98-137.

Jones A.: Gendercide and Genocide. In: Gendercide and Genocide. Ed. A. Jones. Nashville 2004, s. 1-38.

Jones O.B.: Pakistan. Oko cyklonu. Przeł. M. Żytomirski. Warszawa 2005.

Karen E.: The Grip of Sexual Violence: Reading United Nations Security Council Resolutions on Human Security. In: Rethinking Peacekeeping, Gender Equality and Collective Security. Eds. G. Heathcote, D. Otto. London 2014, s. 23-47.

Lemarchand R.: The Burundi Genocide. In: Teaching about Genocide: Issues, Approaches, and Resources. Ed. S. Totten. Greenwich 2004, s. 155-168.

Leydesdorff S.: Surviving the Bosnian Genocide. The Women of Srebrenica Speak. Transl. K. Richardson. Bloomington-Indianapolis 2011.

Mann M.: The Dark Side of Democracy. Explaining Ethnic Cleansing. Cambridge 2006.

March J.G., Olsen J.P.: Instytucje. Organizacyjne podstawy polityki. Przeł. D. Sielski. Warszawa 2005.

Margolin J.-L.: Japonia 1937-1945. Wojna Armii Cesarza. Przeł. J.P. Rurarz, A. Rurarz. Warszawa 2009. 
Markusen E.: Genocide in Bosnia. In: Teaching about Genocide: Issues, Approaches, and Resources. Ed. S. Totten. Greenwich 2004, s. 193-202.

McCormack G.: Reflections on Modern Japanese History in the Context of the Concept of Genocide. In: The Specter of Genocide. Mass Murder in Historical Perspective. Eds. R. Gellately, B. Kiernan. Cambridge 2003, s. 265-286.

Meger S.: Rape of the Congo: Understanding Sexual Violence in the Conflict in the Democratic Republic of Congo. "Journal of Contemporary African Studies" 2010, Vol. 28, no 2, s. 119-135.

Mizielińska J.: Płeć, ciało, seksualność. Od feminizmu do teorii queer. Kraków 2006.

Moczydłowski P.: Drugie życie więzienia. Warszawa 2002.

Muehlenhard Ch.L., Peterson Z.D.: Konceptualizacja przemocy seksualnej. W: Dobro i zło z perspektywy psychologii społecznej. Red. A.G. Miller. Przeł. V. Reder. Kraków 2008, s. 304-338.

Mühlhäuser R.: Between 'Racial Awareness' and Fantasies of Potency: Nazi Sexual Politics in the Occupied Territories of the Soviet Union, 1942-1945. In: Brutality and Desire. War and Sexuality in Europe's Twentieth Century. Ed. D. Herzog. New York 2009, s. 197-220.

Münkler H.: Wojny naszych czasów. Przeł. K. Matuszek. Kraków 2004.

Ostrowska J.: Przemilczane. Seksualna praca przymusowa w czasie II wojny światowej. Warszawa 2018.

Reginia-Zacharski J.: Rwanda. Wojna i ludobójstwo. Warszawa 2012.

Róg U.: Przemoc seksualna we wschodniej części Demokratycznej Republiki Konga. Zarys problemu. W: Kobiety wojny. Między zbrodnią a krzykiem o godność. Red. A. Bartuś. Oświęcim 2014, s. 91-101.

Russell-Brown S.J.: Rape as an Act of Genocide. "Berkeley Journal of International Law" 2003, Vol. 21, no 2, s. 350-374.

Rzymski Statut Międzynarodowego Trybunału Karnego sporządzony w Rzymie dnia 17 lipca 1998 r. „Dziennik Ustaw” 2003, nr 78, poz. 708.

Sadowa K.: Zbrodnie „honorowe” problemem współczesnej Europy? Zarys tematyki. W: Prawo życia i śmierci. Red. M. Sadowski, A. Spychalska, K. Sadowa. Wrocław 2013, s. 209-239.

Scourge of Slavery Still Claims 40 Million Victims Worldwide, 'Must Serve as a Wakeup Call'. "UN News", 9.09.2019. Dostępne w Internecie: https://news.un.org/en/story/ 2019/09/1045972 [data dostępu: 20.09.2019].

Sémelin J.: Analysis of Mass Crime. Ethnic Cleansing in the Former Yugoslavia 1991-1999. In: The Specter of Genocide. Mass Murder in Historical Perspective. Eds. R. Gellately, B. Kiernan. Cambridge 2003, s. 353-370.

Sennerteg N.: Zemsta Stalina 1944-1945. Przeł. W. Łygaś. Warszawa 2007.

Shaw M.: The General Hybridity of War and Genocide. "Journal of Genocide Research" 2007, Vol. 9, Issue 3, s. 461-473.

Skocpol Th.: Social Revolutions in the Modern World. Cambridge 1994.

Soldiers Who Rape, Commanders Who Condone. Sexual Violence and Military Reform in the Democratic Republic of Congo. New York 2009.

Stöcker-Sobelman J.: Kobiety Holokaustu. Feministyczna perspektywa w badaniach nad Shoah. Kazus KL Auschwitz-Birkenau. Warszawa 2012. 
Taylor Ch.: The Cultural Face of Terror in the Rwandan Genocide of 1994. In: Annihilating Difference. The Anthropology of Genocide. Ed. A.L. Hinton. Berkeley-Los Angeles-London 2002, s. 137-178.

Ternon Y.: Ormianie. Historia zapomnianego ludobójstwa. Przeł. W. Brzozowski. Kraków 2005.

Tochman W.: Dzisiaj narysujemy śmierć. Wołowiec 2010.

Uesseler R.: Wojna jako usługa. Jak prywatne firmy wojskowe niszcza demokrację. Przeł. M. Kalata. Warszawa 2008.

Vigarello G.: Historia gwałtu. Od XVI do XX wieku. Przeł. A. Leyk. Warszawa 2010.

LeCH M. Nijakowski - dr hab. nauk społecznych, profesor uczelni w Instytucie Socjologii Uniwersytetu Warszawskiego. Jego zainteresowania badawcze koncentrują się na: studiach nad ludobójstwem, socjologii etniczności, socjologii konfliktu, socjologii historycznej, studiach nad pamięcią zbiorową, analizie dyskursu, współczesnych teoriach socjologicznych. Opublikował sześć samodzielnych monografii naukowych, jest współautorem kolejnych trzech, redaktor lub współredaktor szesnastu tomów zbiorowych. 